\title{
Article \\ Conversion of Scenedesmus rubescens Lipid into Biodiesel by Biochar of Different Origin
}

\author{
Vasiliki D. Tsavatopoulou ${ }^{1}$, Andriana F. Aravantinou ${ }^{1}$, John Vakros ${ }^{2, *}$ and Ioannis D. Manariotis ${ }^{1, *}$ (D) \\ 1 Environmental Engineering Laboratory, Department of Civil Engineering, University of Patras, \\ 26504 Patras, Greece; vasoutsav@gmail.com (V.D.T.); andriana.aravantinou@gmail.com (A.F.A.) \\ 2 Department of Chemistry, University of Patras, 26504 Patras, Greece \\ * Correspondence: vakros@chemistry.upatras.gr (J.V.); idman@upatras.gr (I.D.M.); \\ Tel.: +30-2610-996535 (I.D.M.)
}

Citation: Tsavatopoulou, V.D.; Aravantinou, A.F.; Vakros, J.; Manariotis, I.D. Conversion of Scenedesmus rubescens Lipid into Biodiesel by Biochar of Different Origin Catalysts 2021, 11, 1116. https:// doi.org/10.3390/catal11091116

Academic Editor: Gloria Fernandez-Lorente

Received: 28 August 2021

Accepted: 15 September 2021

Published: 16 September 2021

Publisher's Note: MDPI stays neutral with regard to jurisdictional claims in published maps and institutional affiliations.

Copyright: (c) 2021 by the authors. Licensee MDPI, Basel, Switzerland. This article is an open access article distributed under the terms and conditions of the Creative Commons Attribution (CC BY) license (https:// creativecommons.org/licenses/by/ $4.0 /)$.

\begin{abstract}
One of the most recent applications studied in recent years is the use of biochar as a catalyst for the conversion of oils into biodiesel. The scope of this work was to evaluate the efficiency of biochars as heterogeneous catalysts for the conversion of Scenedesmus rubescens lipids into biodiesel. Biochar from different materials were employed, namely, malt spent rootlets (MSR), coffee spent grounds (CSG), and olive kernels (OK). Materials were charred at two temperatures $\left(400\right.$ and $\left.850{ }^{\circ} \mathrm{C}\right)$ in order to examine the effect of pyrolysis temperature. Homogeneous catalysts such as sulfuric acid and sodium hydroxide were also employed for comparison purposes. In order to explain the different performance of biochar as catalyst, we conducted detailed characterization of these materials. The results of this study showed that homogeneous catalysts $\left(\mathrm{H}_{2} \mathrm{SO}_{4}\right.$ and $\left.\mathrm{NaOH}\right)$ had similar results to the CSG biochar at $400{ }^{\circ} \mathrm{C}$, which was the most productive tested biochar. The pyrolysis temperatures affected the FAMEs recovery of OK and CSG biochar.
\end{abstract}

Keywords: biochar; microalgae; FAMEs; biodiesel; malt spent rootlets; coffee spent grounds; olive kernels

\section{Introduction}

In view of the commitment of EU member countries to be climate-neutral with net zero greenhouse gas (GHG) emissions by 2050, scientists have focused their effort in new negative emissions technologies [1]. They provide emphasis on the development of efficient technologies that are directly related to carbon dioxide reduction into the environment $[2,3]$, such as the production of bioenergy through photosynthesis and the valorization of biomass for the production of biofuels or solid materials such as biochar [4]. One popular approach for biodiesel production is the use of microalgae, which is considered to be one of the most promising renewable sources for biofuel production with high $\mathrm{CO}_{2}$ fixation rates [5]. Microalgae biomass production is a new growing sector that has been boosted in recent years because of the increasing demand for algal biomass. Their biomass has been used in many industrial applications such as in aquaculture feed, medicine, cosmetics, and human nutrition (superfood) [6]. The high lipid content of algal biomass and the need for new renewable energy sources place them on the top of biofuel production. Many studies have focused on specific strain species due to their high lipid content. One of these is Scenedesmus rubescens, also known as Halochlorella rubescens, with high lipid content, which varies from 10 to $72 \%$ [7-9]. The lipid can be transformed to bio oil through transesterification/esterification reaction with methanol. This is the most efficient method for the production of bio oil. Usually, transesterification of algal oil can be performed with the use of acid or base as catalysts $[10,11]$. The state-of-the-art catalyst for the transesterification reaction is the $\mathrm{NaOH}$ solution in methanol, as it is cheap and highly active. Unfortunately, this process is homogenous, and therefore it is difficult to separate the catalyst and to reuse it. Moreover, if the lipids have a significant amount of 
acids, the $\mathrm{NaOH}$ reacts with them to produce soap and is deactivated. These disadvantages can be overcome with the use of a solid catalyst $[12,13]$. The catalyst should have high activity and basicity, resistance to acids, and significant stability. Among the possible candidates, the use of biochar as a catalyst is a new process that is recently investigated [12]. Biochar is a carbonaceous material usually produced as a byproduct of the valorization of biomass. It has interesting properties and exhibits high amount of surface sites with tunable acidity/basicity. Biochar is a low-cost material and can be prepared from any biomass (safflower seed press cake, olive husk, poultry manure, rice husk, peanut shells, palm-kernel shell, grape pomace, bio sludge from pulp mill, watermelon peel, spent coffee grounds, malt spent rootlets, etc.) with pyrolysis under free or limited oxygen atmosphere [14,15]. Its chemical composition varies and depends mainly on the feedstocks used and the pyrolysis conditions such as temperature and atmosphere [4]. It can be used in many environmental processes as a catalyst for the oxidation of emerging compounds [16], a catalyst for the transesterification for biodiesel production [17], a supercapasitor [18], and a sorbent $[15,19]$, among other uses. Generally, the biochar exhibits great stability, even under oxidative conditions and a significant number of surface-active sites [20].

Temperature is the fundamental and crucial factor in the pyrolysis process. Usually, pyrolysis temperature ranges from 200 to $1000{ }^{\circ} \mathrm{C}$ for the degradation of biomass, and many studies have tried to explain the effect of temperature on the product yield and quality $[14,15,21]$. It is widely accepted that pyrolysis temperature can influence the surface active sites; the composition of the biochar; and textural properties such as specific surface area, pore volume, and pore size distribution. These properties determine the activity of the biochar in many processes, among them, in transesterification and, thus, the produced quantity and quality of biodiesel [14]. The transesterification reaction occurs in the inert pores of biochar material and the pyrolysis temperature determines the surface functional groups of the biochar, and thus these two factors affect the produced biodiesel [14]. Sotoudehniakaran et al. (2019) used Chlorella vulgaris biomass pyrolyzed at 450, 500, and $550{ }^{\circ} \mathrm{C}$, and reported that the highest bio-oil yield was $47.7 \%$ at $550^{\circ} \mathrm{C}$ while the lowest yield was lower than $30.0 \%$ at $450{ }^{\circ} \mathrm{C}$ [22].

The aim of this work was to investigate the use of biochar as a heterogeneous catalyst for the conversion of algal lipid into biodiesel. The effect of feedstock and pyrolysis temperature were investigated. Specifically, biochar was produced from malt spent rootlets (MSR), coffee spent grains (CSG), and olive kernels (OK) at pyrolysis temperatures of 400 and $850{ }^{\circ} \mathrm{C}$. For comparison purposes, common homogeneous catalysts were also used, including an acidic $\left(\mathrm{H}_{2} \mathrm{SO}_{4}\right)$ and a basic $(\mathrm{NaOH})$. Finally, the most efficient case scenario was estimated, and the quality of the produced biodiesel was analyzed for each case. According to our knowledge, this is the first study comparing the effect of feedstock type and pyrolysis temperature of biochar for the conversion of algal lipid into biodiesel.

\section{Results}

\subsection{Biochar Properties}

The six biochars were prepared using three different raw biomass sources, olive kernels (OK), malt spent rootlets (MSR), and coffee spent grounds (CSG), under two different pyrolysis temperatures, 400 and $850{ }^{\circ} \mathrm{C}$, symbolized as OKX, MSRX, and CSGX, respectively, where $\mathrm{X}$ denotes the pyrolysis temperature.

\subsubsection{SEM and EDX Analysis}

The morphology of biochar produced at two temperatures $\left(400\right.$ and $\left.850{ }^{\circ} \mathrm{C}\right)$ was studied by scanning electron microscopy (SEM) analysis and is illustrated in Figure 1. Elemental analysis on the samples surface was also conducted, and the results are shown in Table 1. 
$400{ }^{\circ} \mathrm{C}$
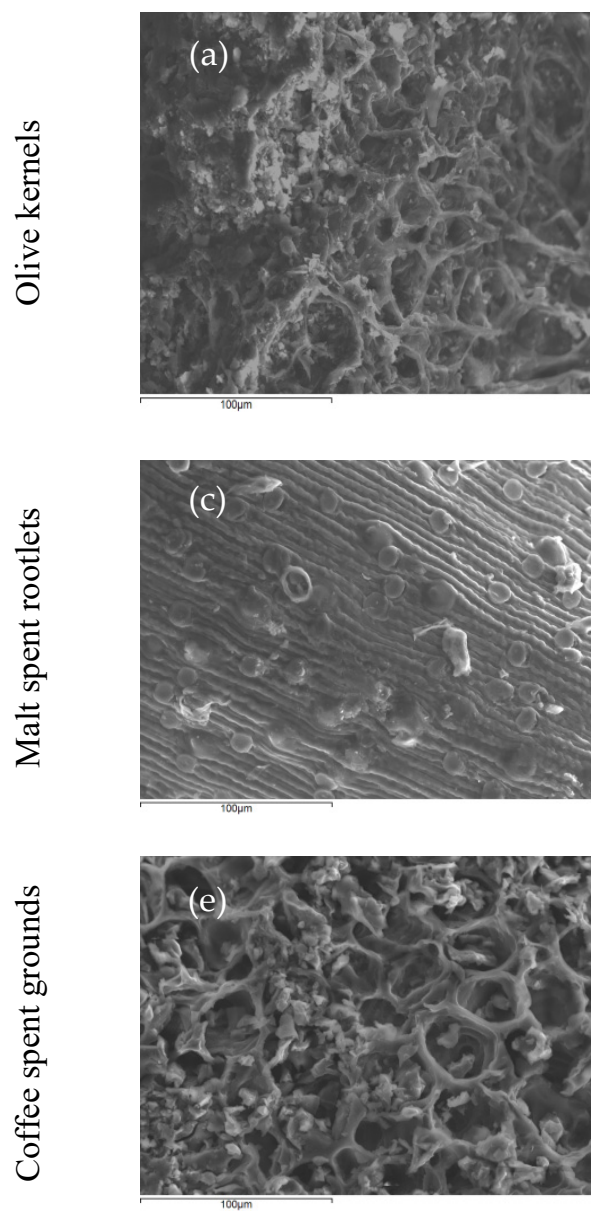

$850{ }^{\circ} \mathrm{C}$
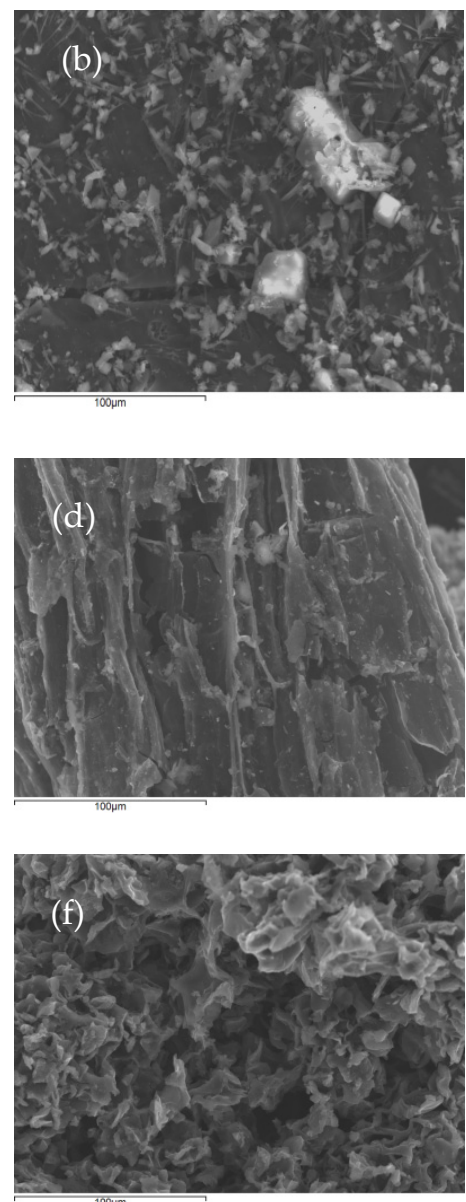

Figure 1. SEM images of the prepared biochars: (a) OK400, (b) OK850, (c) MSR400, (d) MSR850, (e) CSG400, and (f) CSG850.

Table 1. Atomic content (\%) of elements of the studied biochars determined by the EDX analysis. Carbon was not used in the calculations. (N.D.: not detected)

\begin{tabular}{ccccccc}
\hline Element & OK400 & OK850 & MSR400 & MSR850 & CSG400 & CSG850 \\
\hline $\mathrm{O}$ & 15.75 & 17.38 & 47.06 & 42.23 & 31.8 & 34 \\
$\mathrm{Mg}$ & N.D. & N.D. & 2.83 & 15.27 & 11.47 & 12.46 \\
$\mathrm{Si}$ & N.D. & N.D. & 26.38 & N.D. & N.D. & N.D. \\
$\mathrm{P}$ & 2.15 & 2.08 & 8.67 & 21.61 & 9 & 11.53 \\
$\mathrm{Cl}$ & 45.33 & 36.76 & N.D. & N.D. & N.D. & N.D. \\
$\mathrm{K}$ & N.D. & 4.94 & 10.58 & 20.9 & 33.04 & 30.08 \\
$\mathrm{Ca}$ & 3.42 & 3.21 & 4.48 & N.D. & 14.69 & 11.93 \\
$\mathrm{Na}$ & 33.36 & 35.64 & N.D. & N.D. & N.D. & N.D. \\
\hline
\end{tabular}

According to the SEM images, the increase of pyrolysis temperature affects the surface structure. As shown in Figure $1 \mathrm{a}, \mathrm{b}$, the OK catalyst sample had a porous structure and, more specifically, the pores of olive kernels at $400{ }^{\circ} \mathrm{C}$ seemed to be larger than those at $850{ }^{\circ} \mathrm{C}$. On the contrary, the microstructure of MSR produced channel-like formations, which were denser than in the case of $400^{\circ} \mathrm{C}$ (Figure 1c,d). Discrete pores were visible both in CGS at $400^{\circ} \mathrm{C}$ and $850{ }^{\circ} \mathrm{C}$ (Figure $1 \mathrm{e}, \mathrm{f}$ ).

EDX analysis revealed the presence of various atoms on the surface of produced biochar, including carbon $(\mathrm{C})$ and oxygen $(\mathrm{O})$ as major compounds, as was expected. In order to detect the percentages of the elements contained, we did not take the percentage 
of carbon into consideration. In olive kernels biochars, the elements that were detected were $\mathrm{P}, \mathrm{Cl}, \mathrm{Ca}$, and $\mathrm{Na}$, for the OK400 and for OK850 K was also detected. Coffee spent grounds maintained approximately the same proportions in elements $(\mathrm{Mg}, \mathrm{P}, \mathrm{K}$, and $\mathrm{Ca}$ ) at both 400 and $850^{\circ} \mathrm{C}$. In malt spent rootlets, the content of $\mathrm{Mg}$, $\mathrm{P}$, and $\mathrm{K}$ increased at $850{ }^{\circ} \mathrm{C}$ compared to $400{ }^{\circ} \mathrm{C}$, while Si and Ca also appeared at $400{ }^{\circ} \mathrm{C}$. Generally, the content of the metal ions increased with the pyrolysis temperature. This was the result of greater removal of inorganic volatile compounds such as $\mathrm{Cl}$ in OK850 biochar and especially carbon phase due to higher temperature in all biochars. Only in the CSG biochar was this unable to be clearly seen due to the very low content of the minerals, as was confirmed from the TGA results.

\subsubsection{XRD and FTIR Analysis}

The XRD patterns are presented in Figure 2 for the biochar prepared.
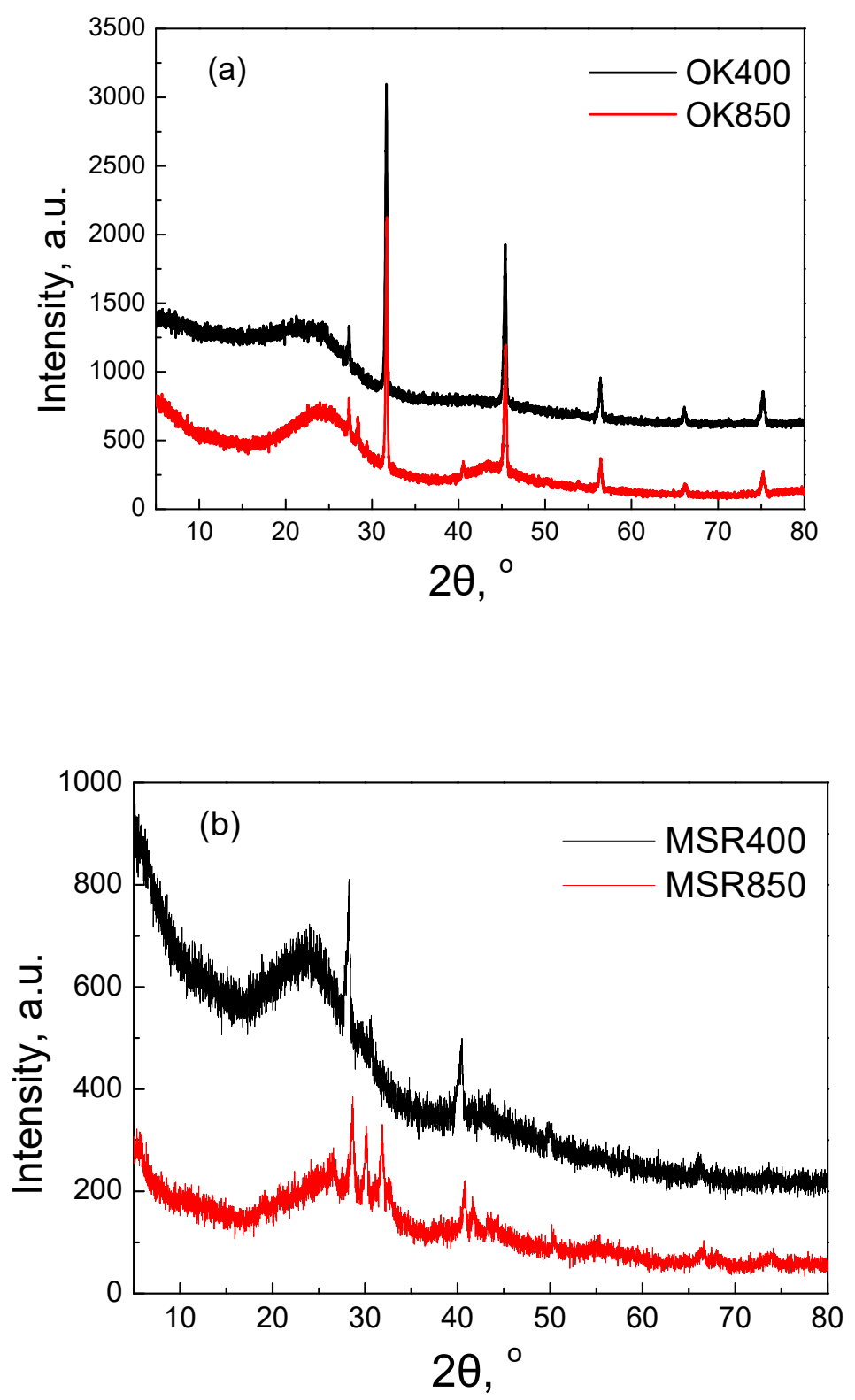

Figure 2. Cont. 


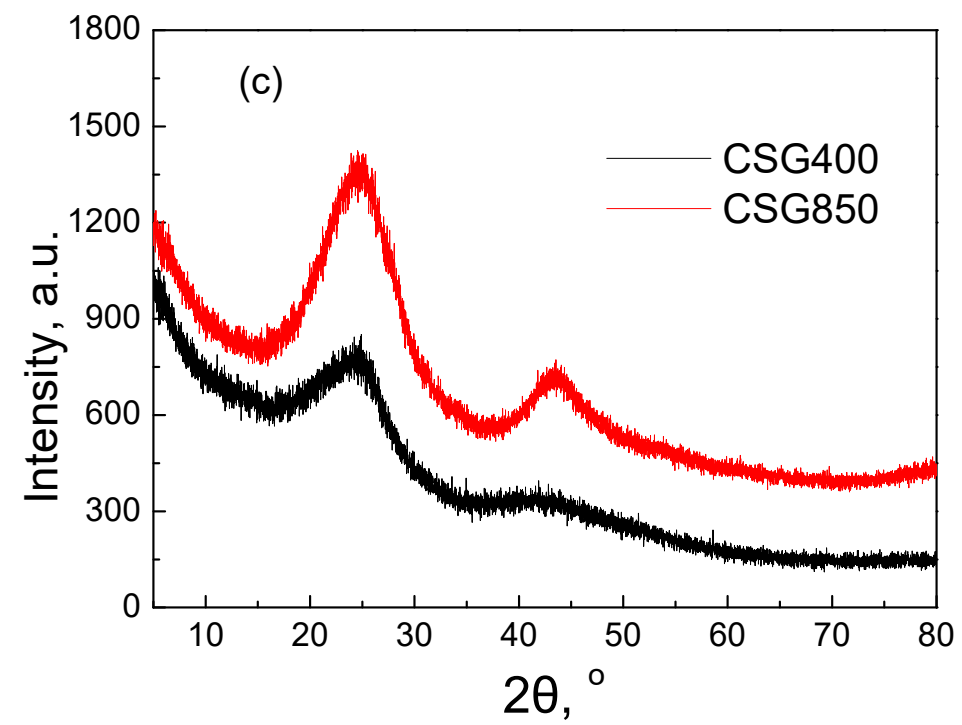

Figure 2. XRD patterns of the prepared biochars: (a) OK400 and OK850, (b) MSR400 and MSR850, (c) CSG400 and CSG850.

As can be seen, the XRD patterns had significant differences depending on the raw biomass, and some biochars had intense and sharp peaks. These peaks describe the presence of minerals on the biochars. This was due to the presence of these elements in the raw biomass. During pyrolysis, the volatile inorganic compounds were released, and the other inorganic elements were transformed into oxides, carbonates, or the stable inorganic phase. The pyrolysis process burnt a significant amount of the carbonaceous phase, and, as a result, the concentration of the inorganic phase increased. For example, the OK biochars had intense and sharp peaks identified as halite. This was also supported by the EDS analysis and previous results [23]. The crystallites had a mean size of of $35.0 \mathrm{~nm}$ for the halite in OK400 and $45.8 \mathrm{~nm}$ for OK850, pointing out that the high temperature pyrolysis increased the crystallites size, as was expected.

The XRD patterns of the MSR are more complex since there are more elements in the raw biomass. It has been found that the raw biomass has, by weight, $2 \% \mathrm{Ca}, 1 \% \mathrm{P}, 0.2 \% \mathrm{~K}$, $0.1 \% \mathrm{Na}, 0.01 \%, \mathrm{Fe}, 0.01 \% \mathrm{Mg}$, and $0.01 \% \mathrm{Zn}$ [24]. During pyrolysis, these elements were transformed to inorganic phase such as calcite ( $21.7 \mathrm{~nm}$ mean crystallite size), whewellite (33.4 $\mathrm{nm}$ mean crystallite size), kalicinite ((25.6 nm mean crystallite size), and sodium carbonate and halite (30.6 nm mean crystallite size) [25], especially at high temperature. At low temperature, the presented crystallites were smaller, pointing out again the sintering effect of the high temperature pyrolysis. Finally, the CSG biochar did not exhibit sharp peaks, pointing out the absence of inorganic phases.

The carbonaceous phase was present in all biochar, and it can be described from the two broad peaks at about $22^{\circ}$ and $43.3^{\circ}$. The first peak can be assigned to (002), while the second to (100) crystal planes of hard carbon in lignocellulose form. These peaks were more intense after pyrolysis at $850^{\circ} \mathrm{C}$. The first broad peak was typical of a carbonaceous material with a less ordered structure due to pyrolysis. The second peak can be ascribed to structures where the $\mathrm{C}$ has $\mathrm{sp}^{2}$ hybridization since it represents the graphitic structure, which improves electrical conductivity [26,27].

The FTIR spectra of biochars are presented in Figure 3. Generally, the spectra had more peaks at a pyrolysis temperature of $400{ }^{\circ} \mathrm{C}$ and were less complicated for the biochars prepared at higher pyrolysis temperature. This can be attributed to the removal of $C$ and $\mathrm{O}$ species due to high temperature. This was also observed for the biochar from rice husk [16]. Generally, there were five peaks-their intensity changed with the pyrolysis temperature and the raw biomass. The peak at about $3400 \mathrm{~cm}^{-1}$, presented in all biochars, was due to $-\mathrm{OH}$ groups and adsorbed water molecules. This peak was less intense with 
the temperature due to the greater extent of burning, in accordance with the EDX results. The peak at $1090 \mathrm{~cm}^{-1}$ describes the symmetric C-O stretching and had the same trend, with the exception of MSR850. This was probably due to the high amount of minerals presented in this biochar, which increased after pyrolysis. The peaks at about $1600 \mathrm{~cm}^{-1}$ can be attributed to $C=C$ groups, pointing out that the carbon phase had a significant aromatic character. This aromatic phase was poor in $\mathrm{H}$ since no peaks could be detected above $3000 \mathrm{~cm}^{-1}$. Finally, the low intensity of the peaks in the region $1000-1800 \mathrm{~cm}^{-1}$ for the biochars prepared at $850{ }^{\circ} \mathrm{C}$ was characteristic of heterogeneity of the above biochars.

\subsubsection{Specific Surface Area (SSA) Determination}

The values of SSA were determined with the BET method from the adsorption data of $\mathrm{N}_{2}$ at liquid $\mathrm{N}_{2}$ temperature. The values are presented in Table 2. As can be seen, all the biochars prepared at $400{ }^{\circ} \mathrm{C}$ had very small surface areas, while the pyrolysis temperature increased the SSA values to higher values. As was expected, only the biochars prepared at high pyrolysis temperature had a significant amount of micropores. Moreover, the biochars prepared at $850^{\circ} \mathrm{C}$ had measurable pore volume (Table 2).

Table 2. Physicochemical characteristics of the biochars studied.

\begin{tabular}{|c|c|c|c|c|c|c|}
\hline Biochar & SSA & $\begin{array}{c}\text { Micropores } \\
\text { SSA }\end{array}$ & $\begin{array}{c}\text { Pore } \\
\text { Volume }\end{array}$ & $\begin{array}{c}\text { TGA } \\
\text { Minerals }\end{array}$ & $\underset{\left(\mathrm{H}_{2} \mathrm{O}\right)}{\mathrm{pH}}$ & $\begin{array}{c}\mathrm{pH} \\
\left(\mathrm{H}_{2} \mathrm{O}-\mathrm{MeOH}\right)\end{array}$ \\
\hline & $\left(m^{2} g^{-1}\right)$ & $\left(m^{2} g^{-1}\right)$ & $\left(\mathrm{mL} \mathrm{g}^{-1}\right)$ & $(\%)$ & & \\
\hline OK400 & 0.1 & - & - & 8 & 6.9 & 7.2 \\
\hline OK850 & 107 & 69 & 0.01 & 11 & 10.5 & 10.0 \\
\hline MSR400 & 0.04 & - & - & 14 & 7.7 & 7.8 \\
\hline MSR850 & 125 & 74 & 0.1 & 35 & 11.4 & 11.2 \\
\hline CSG400 & 0.4 & - & - & 2 & 8.1 & 9.5 \\
\hline CSG850 & 307 & 217 & 0.15 & 3 & 10.7 & 10.5 \\
\hline
\end{tabular}

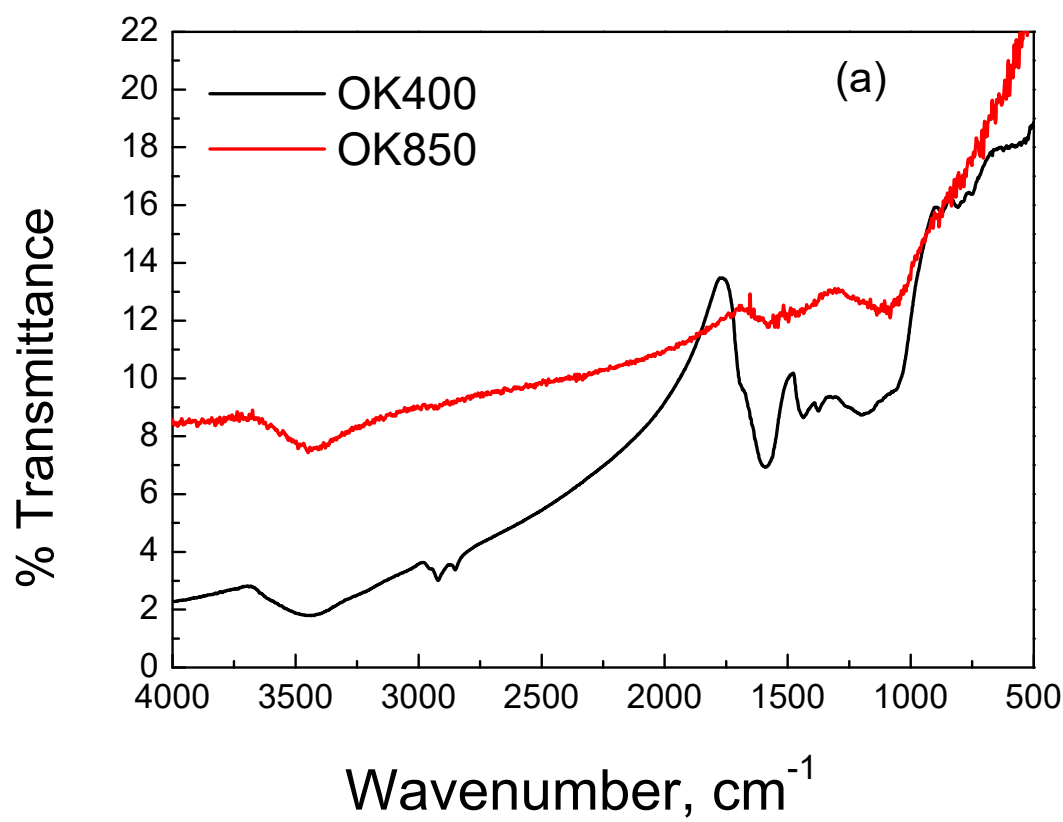

Figure 3. Cont. 

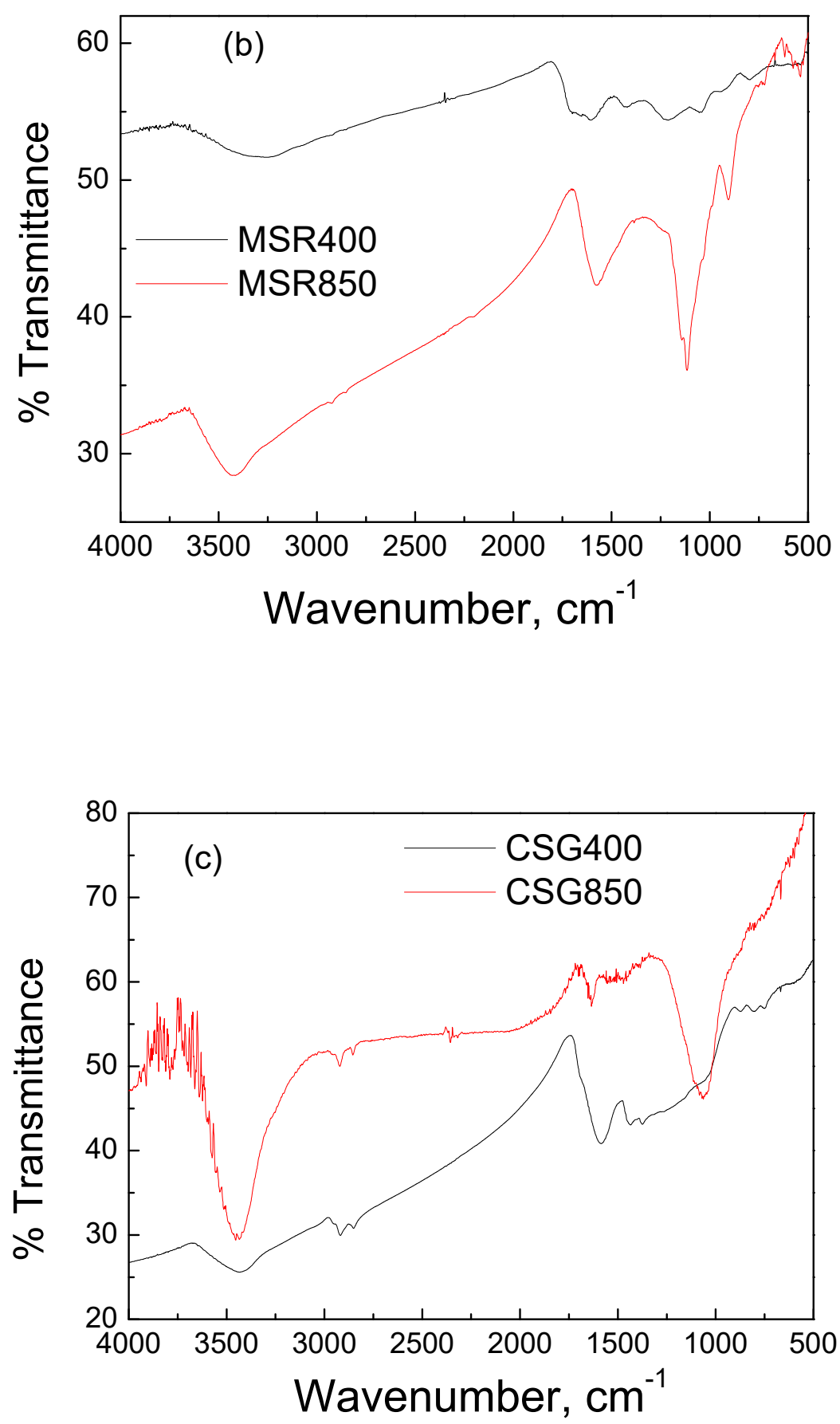

Figure 3. FTIR spectra of the prepared biochars: (a) OK400 and OK850, (b) MSR400 and MSR850, (c) CSG400 and CSG850.

\subsubsection{Thermogravimetric Analysis (TGA)}

TGA was performed under air atmosphere with a heat rate of $10{ }^{\circ} \mathrm{C} \mathrm{min}{ }^{-1}$. Under these conditions, the carbonaceous phase was expected to fully burn, and the residuals were due to minerals and nonvolatile inorganic phase. The TGA curves are presented in Figure 4, while the mass left after TGA experiments is reported in Table 2. 


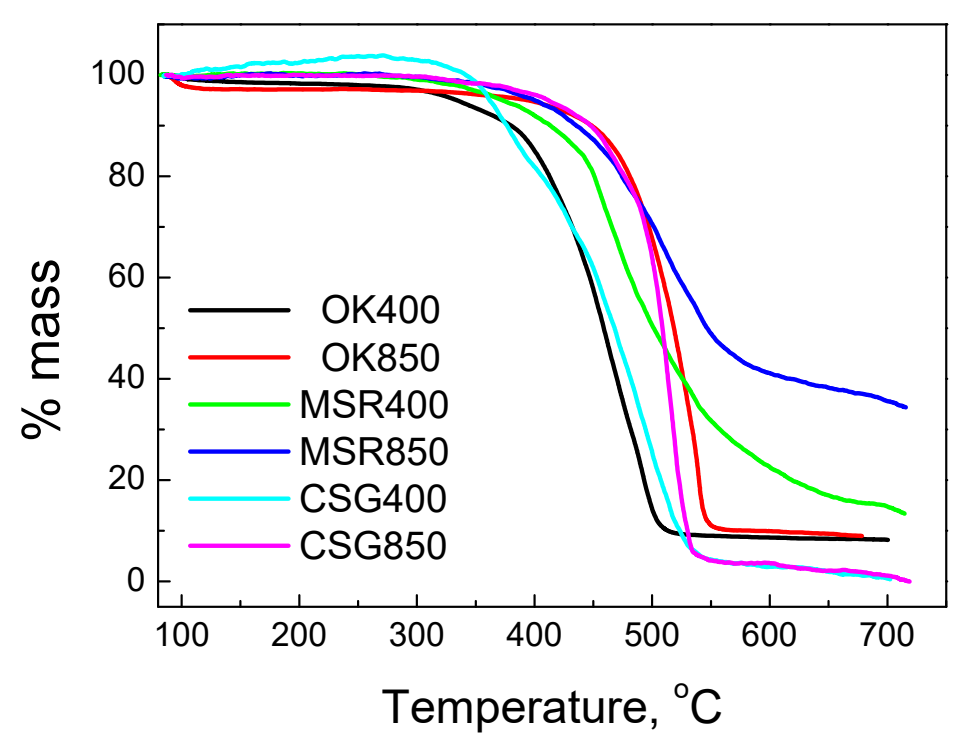

Figure 4. TGA curves under air atmosphere of the biochars studied.

As can be seen from the TGA curves, the mass of each biochar was stable in temperatures lower than 300 to $350{ }^{\circ} \mathrm{C}$. In higher temperatures, a sharp decrease of the biochar's mass can be seen. The temperature that the sharp decrease occurred in was different for each biochar. This is evidence that two parameters can influence the stability of the biochar: the starting biomass and the pyrolysis temperature. As can be seen, the increment of pyrolysis temperature increased the stability of biochar and thus the decomposition temperature. This was valid for all biochars, irrespective of the raw biomass. The raw biomass also affected the stability. The differences were more important in the low pyrolysis temperature, suggesting that at high pyrolysis temperatures, the carbon phase was similar, irrespective of the raw biomass. The main difference for the biochars prepared at $850{ }^{\circ} \mathrm{C}$ was the amount of minerals, which changed the mass left after TGA. In the lower pyrolysis temperature, the differences in carbonaceous phase were more pronounced, although OK and CSG had similar behavior. As can be concluded from the TGA curves at higher pyrolysis temperatures, the carbon phase was transformed to "harder" carbon phase in accordance with the XRD and FTIR results.

The amount of the minerals can be estimated by the mass left in TGA run. MSR biochar contained higher amount of minerals, while the higher pyrolysis temperature increased the amount of minerals due to the removal of volatile inorganic phase and part of carbonaceous phase of the raw biomass.

\subsubsection{Acid-Base Behavior of Biochars}

The suspension's $\mathrm{pH}$ of the biochars are presented in Table 2. The $\mathrm{pH}$ was measured either in water suspension or in water/methanol suspension after $24 \mathrm{~h}$ of equilibration. As can be seen, generally, the suspension had high $\mathrm{pH}$ values, especially after pyrolysis at $850{ }^{\circ} \mathrm{C}$. This can be attributed to the present of minerals, although this was not valid for the CSG, since no minerals were presented on these biochars. Thus, the high $\mathrm{pH}$ value was due to the removal of acidic surface - $\mathrm{OH}$ groups such as phenolic or carboxy groups. These groups, with acidic character, formed $\mathrm{CO}$ and $\mathrm{CO}_{2}$ and were removed during the pyrolysis. This high basicity of biochars is expected to be significant in the transesterification process where the activation of $\mathrm{MeOH}$ is required. The base catalyst can activate $\mathrm{MeOH}$, interacting with the $\mathrm{H}$ and forming the $\mathrm{MeO}^{-}$, which is the active species for the transesterification process. The presence of $\mathrm{MeOH}$ in the suspension did not significantly alter the results. This was expected since it was found in a previous study, where the ATR FTIR spectra of biochars from MSR were recorded in the presence of methanol. It was found that $\mathrm{MeOH}$ can interact with basic surface sites and diminished the surface -OH groups to form methoxide [17]. This can either be released in the mixed 
solution, where it will react with water molecules, increasing the $\mathrm{pH}$, or stay adsorbed. In the transesterification process, where water molecules are absent, the methoxide is the active species for the transesterification.

\subsection{Transesterification Results}

Heterogeneous catalysts may convert oils into biodiesel slowly; however, their separation from the reaction mixture is easy, in contrast with homogeneous catalysts [28]. The six biochars were tested for their transesterification activity using the lipid extracted from microalgae Scenedesmus rubescens. Biodiesel production involves three successive reactions of the natural triglycerides, contained in oils with a low molecular weight alcohol and the use of a strong catalyst. Moreover, the determined performance of the solid catalysts was compared with the corresponding performance of homogenous catalyst.

Among the biochars, the highest mass recovery of FAMEs was $25.7 \mathrm{mg}$ for CSG400 and $21.34 \mathrm{mg}$ for MSR850. In Table 3, total FAMEs (mg) are shown, delivered by each catalyst. The lowest amounts were yielded by OK850 (16.35 mg) and MSR400 (16.78 mg).

Table 3. Total mass of FAMEs recovered after transesterification.

\begin{tabular}{cc}
\hline Catalysts & Total FAMEs $(\mathbf{m g})$ \\
\hline $\mathrm{H}_{2} \mathrm{SO}_{4}$ & 27.55 \\
$\mathrm{NaOH}$ & 29.04 \\
$\mathrm{MSR} 850$ & 21.34 \\
$\mathrm{MSR} 400$ & 16.78 \\
$\mathrm{OK} 850$ & 16.35 \\
$\mathrm{OK} 400$ & 19.12 \\
$\mathrm{CSG850}$ & 18.96 \\
$\mathrm{CSG} 400$ & 25.70 \\
\hline
\end{tabular}

The oil extracted from algal biomass is mainly composed of unsaturated fatty acids such as palmitoleic, oleic, linoleic, and linolenic acids [29]. The GC chromatograms of produced biodiesel from the MSR, OK, and CGS biochar catalysts and homogenous catalysts $\left(\mathrm{H}_{2} \mathrm{SO}_{4}\right.$ and $\left.\mathrm{NaOH}\right)$ were analyzed in order to determine their content of methyl esters. The results showed the presence of a specific range of methyl esters (C16:0-C18:2n6c) between biochars, while $\mathrm{H}_{2} \mathrm{SO}_{4}$ and $\mathrm{NaOH}$ showed even more (C13:0-methyl tridecanoate for $\mathrm{H}_{2} \mathrm{SO}_{4}$ and $\mathrm{C} 18: 3 \mathrm{n} 6$-methyl linolenate for both). Methyl palmitate (C16:0), methyl stereate (C18:0), methyl oleate (C18:1), methyl linoleate (C18:2), and methyl linolenate (C18:3) are suitable candidates for biodiesel production [30]. Olive kernels, regardless of the pyrolysis temperature, at 400 and $850{ }^{\circ} \mathrm{C}$, resulted the same methyl esters, such as C16:0 (methyl palmitate), C18:0 (methyl stearate), and C18:1n9c (methyl octadecenoate). The same pattern was produced by MSR at $400{ }^{\circ} \mathrm{C}$ and CSG at $850{ }^{\circ} \mathrm{C}$. However, this was not shown in the other two biochars at both temperatures (MSR and CSG). MSR at $850{ }^{\circ} \mathrm{C}$ and CSG at $400{ }^{\circ} \mathrm{C}$ presented beyond C16:0 (methyl palmitate) and C18:2n6c (methyl linoleate) for both, also producing C18:1n9c (methyl octadecenoate) for the former and C18:0 (methyl stearate) for the latter (Figure 5). The main methyl ester in all cases was methyl palmitate (C16:0), which is one of the biodiesel components that provides the highest ketene response [31]. Specifically, in the case of CSG400, the percentage of C16:0 was 51.6\%. In the case of algal lipid, the use of an acidic catalyst seems to be more efficient for obtaining biodiesel, since algal oil has many polyunsaturates [32]. Generally, base-catalyzed transesterification, in the presence of water or free fatty acid (FFA), could significantly lower the biodiesel yield due to saponification reaction [33]. Homogeneous acidic $\left(\mathrm{H}_{2} \mathrm{SO}_{4}\right)$ or basic $(\mathrm{NaOH})$ catalysts were used and compared to the biochar CSG at $400{ }^{\circ} \mathrm{C}$, which was the most productive in terms of recovered amounts of FAMEs (Figure 6). CSG400 produced more C16:0 than $\mathrm{NaOH}$ and came as a performance very close to $\mathrm{H}_{2} \mathrm{SO}_{4}$. As far as $\mathrm{C} 18: 0$ and $\mathrm{C} 18: 3 \mathrm{n} 6$ were concerned, CSG400 also had a better yield. 

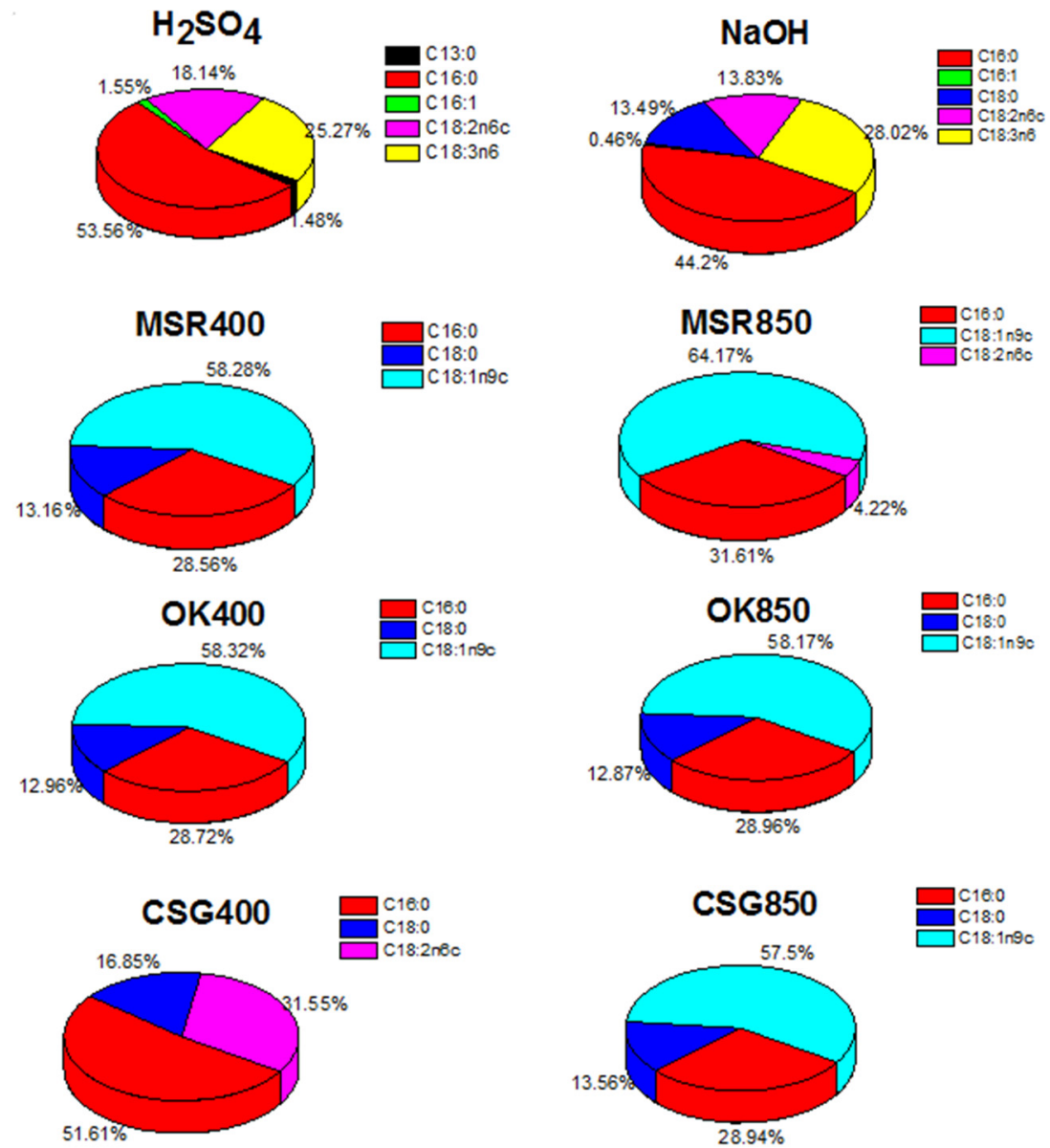

Figure 5. Content of methyl esters produced via $\mathrm{H}_{2} \mathrm{SO}_{4}, \mathrm{NaOH}$, and $\mathrm{MSR}$ at 400 and $850{ }^{\circ} \mathrm{C} ; \mathrm{OK}$ at 400 and $850{ }^{\circ} \mathrm{C}$; and CSG at 400 and $850{ }^{\circ} \mathrm{C}$.

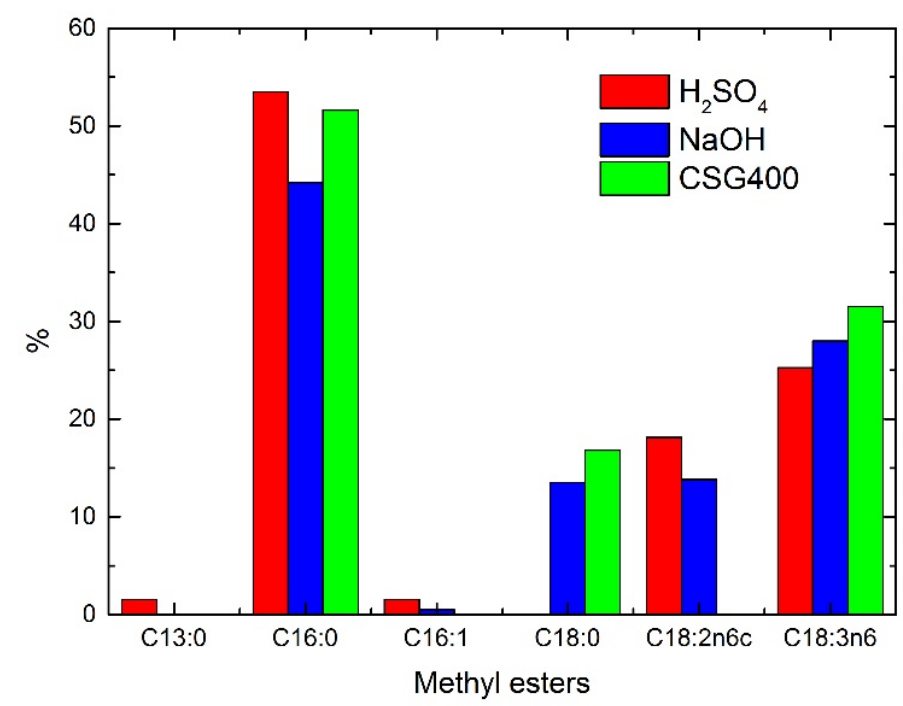

Figure 6. Methyl esters produced by $\mathrm{H}_{2} \mathrm{SO}_{4}, \mathrm{NaOH}$, and CSG400.

\section{Discussion}

The pyrolysis temperature and the origin of biomass can significantly affect the catalytic properties of the biochar. It was found that pyrolysis at $850{ }^{\circ} \mathrm{C}$ increased the surface basicity and the SSA values, although the increment in SSA was due to micropores surface area. The activity was generally lower, with the exception of MSR850, when 
the biochar was formed in high temperature, pointing out that the surface area was not mandatory for the process. This was probably due to the high dimension of the lipids. Indeed, the lipids were not easily transported through the small micropores either due to mass transfer phenomena or physical exclusion. On the other hand, the MSR biochar also had a significant amount of macropores, as they retained the macroporosity due to malt rootlets of the starting biomass. FAMEs' kinetic diameter ranged from 0.8 to $1.5 \mathrm{~nm}$ and methanol's diameter was $0.4 \mathrm{~nm}$. Generally, the kinetic diameter of triglycerides (TGs) was 10 times larger than FAMEs. Thus, a catalyst with bigger pore size such as MSR850 allows the TGs and methanol to access the pores more easily.

The acidity/basicity of the biochars is complicated. Generally, the suspension $\mathrm{pH}$ was located in a high basic area for the samples prepared at $850{ }^{\circ} \mathrm{C}$, while the corresponding biochars from $400{ }^{\circ} \mathrm{C}$ had lower $\mathrm{pH}$ values in a suspension. This can be attributed to the removal of acidic surface groups at a higher pyrolysis temperature, but it reveals that a good catalyst should have a balanced amount of acidic and basic sites, especially for the transesterification of algae lipids wherein a significant amount of free fatty acids exist. This can explain the higher activity of the OK400 and especially the CSG400. Keeping in mind that biochars from OK and CSG have lower mineral content, and in the case of OK this is $\mathrm{NaCl}$ with no acid or base ability, the removal of surface oxygen sites due to high pyrolysis temperature can explain the higher performance for OK400 and CSG400 in contrast with OK850 and CSG850. Among these two, CSG can activate MeOH to a greater extent, as can be seen from the shift in $\mathrm{pH}$ in the mixed methanol-water suspension, from 8.1 to 9.5.

The two biochars from MSR had a higher content of minerals. Thus, they had basic properties, which are beneficial for the transesterification activity, although the basicity is general due to the minerals. In this sample, the activation of $\mathrm{MeOH}$ can occur to a significant degree as the $\mathrm{pH}$ suspension in the methanol-water system is higher among the biochars.

The characteristics of the biochar can affect the selectivity of the process. As can be seen, the selectivity profile of the OK400 and OK850 was the same, pointing out that pyrolysis at high temperature does not significantly alter the distribution of active sites. For MSR850 and MSR400, the pyrolysis temperature increases the basicity, and thus C18:0 is formed, in accordance with the results for homogenous catalysis. On the other hand, the main product for the biochar catalysts is C18:1n9C, with the exception of the most active biochar CSG400. Its product distribution is similar with the distribution of the homogenous catalysts, pointing out that the transesterification occurs in the bulk solution, and the high activity is due to the formation of methoxides on the surface and the subsequent release in the bulk solution.

\section{Materials and Methods \\ 4.1. Algal Cultures}

The algal strain Scenedesmus rubescens (SAG 5.95) used in this study was obtained from the SAG Culture Collection of the University of Göttingen. The selection was based on the high lipid content of the specific strain and its potential use for biofuel production. Algal precultures were prepared in a 2 L Erlenmeyer flask with modified 1/3N BG-11 medium (Blue Green-11 enriched with one-third times the nitrate concentration). The flask was under continuous illumination and constant aeration at $3.5 \mathrm{~L} / \mathrm{min}$ (air pump, HP-400, Sunsun, Zhejiang, China), and was placed in a walk-in incubator room under controlled environmental conditions at $20^{\circ} \mathrm{C}$. Then, the quantity of microalgae was transferred from the preculture in $10 \mathrm{~L}$ flasks, in order to obtain from each flask an initial concentration of $100 \mathrm{mg} / \mathrm{L}$ for 16 days. Microalgal biomass was determined by the measurement of total suspended solids (TSS) according to standard methods [34]. The OD650 was 0.176 ABS, and the cell concentration was $5 \times 10^{7}$ cell $/ \mathrm{mL}$ at the beginning of cultivation. The optical density of algal cultures was measured at $650 \mathrm{~nm}$ with a UV-VIS spectrophotometer (U-1100, Hitachi, Japan), and the algal cell concentration was measured with a Neubauer hemocytometer $\left(0.1 \mathrm{~mm}, 0.0025 \mathrm{~mm}^{2}\right.$, Optic Labor, Berlin, Germany) after algae staining 
with Lugol's solution in order to separate the dead from live algae. Anion concentration was determined by ion chromatography (Metrohm 850 Professional IC, Metrohm AG, Herisau, Switzerland), and at the beginning of the cultivation, $\mathrm{NO}_{3}{ }^{-}$and $\mathrm{PO}_{4}{ }^{3-}$ concentrations were 313 and $16 \mathrm{mg} / \mathrm{L}$, respectively. The illumination was provided continuously by $36 \mathrm{~W}$ (cool daylight) fluorescents lamps, which were placed on both sides. The light intensity at the surface of the flasks was $95 \mu \mathrm{mol} \mathrm{m}{ }^{-2} \mathrm{~s}^{-1}$ (Lightscout, Quantum Light Meters, Aurora, CO, USA).

\subsection{Biochar Production}

Malt spent rootlets (MSR) were obtained from the Athenian Brewery S.A. (Patras, Greece). Its chemical composition includes 32\% protein, $11 \%$ fiber, $8.7 \%$ ash, $2.5 \%$ reducing sugars, $0.9 \%$ non-reducing sugars, $27 \%$ starch, $0.02 \%$ phytic acid, $0.4 \%$ polyphenols, $2 \% \mathrm{Ca}$, $1 \% \mathrm{P}, 0.2 \% \mathrm{~K}, 0.1 \% \mathrm{Na}, 0.01 \%, \mathrm{Fe}, 0.01 \% \mathrm{Mg}$, and $0.01 \% \mathrm{Zn}[24,35]$. Coffee spent grounds (CSG) were obtained from local coffee shops, and olive kernels (OK) were obtained from a local enterprise. The pristine materials were placed in an oven at $80{ }^{\circ} \mathrm{C}$; weighted; and placed into a ceramic, custom-made vessel sealed with a ceramic cap, thus retaining a limited oxygen atmosphere, about $20 \%$ of the required $\mathrm{O}_{2}$ for full oxidation. The vessel was placed in a gradient temperature furnace (LH 60/12, Nabertherm GmbH, Lilienthal, Germany) reaching a temperature of $400^{\circ} \mathrm{C}$, and was pyrolyzed for $1 \mathrm{~h}$. The procedure was repeated for one more pyrolysis temperature at $850^{\circ} \mathrm{C}$. Then, the biochar was collected and mechanically sieved to obtain fractions of different particle sizes. Finally, the fraction of particle size smaller than $150 \mu \mathrm{m}$ was chosen and used for the characterization of the samples and the determination of catalytic performance.

\subsection{Physicochemical Characterization of Biochar}

The measurement of specific surface area (SSA), micropore surface area, and pore size distribution was performed with $\mathrm{N}_{2}$ adsorption isotherms at liquid $\mathrm{N}_{2}$ temperature in a Tristar 3000 porosimeter. X-ray diffraction (XRD), and patterns were recorded in a Bruker D8 (Billerica, MA, USA) Advance diffractometer equipped with a nickel-filtered CuKa (1.5418 ̊) radiation source. Fourier transform infrared (FTIR) spectroscopy was performed using a Perkin Elmer Spectrum RX FTIR system. The measurement range was $4000-400 \mathrm{~cm}^{-1}$. The biochar morphology was examined by scanning electron microscopy (SEM JEOL JSM6300) equipped with an Oxford EDS. A small sample was glued to SEM stubs with colloidal silver and sputter-coated with gold-palladium using a gold ion sputter coater (JEOL, JFC1100 Fine Coat). The samples were examined with SEM operating at $20 \mathrm{kV}$. For each sample, at least four fields were observed at different magnifications between 250 and $2500 \times$. Thermogravimetric analysis (TGA) was performed in a TGA PerkinElmer system under air atmosphere, with a heating rate of $10^{\circ} \mathrm{C} / \mathrm{min}$ in the range 50 to $700{ }^{\circ} \mathrm{C}$. To study the acid-base behavior of the biochars, we prepared two suspensions for each sample at a solid to liquid ratio of $0.5 \mathrm{~g}$ to $5 \mathrm{~mL}$, either with pure water or with a mixture of 50/50 water/methanol, since it was not possible to measure $\mathrm{pH}$ in pure methanol. The suspensions were left to equilibrate for $24 \mathrm{~h}$, and then the $\mathrm{pH}$ was measured.

\subsection{Lipid Extraction}

The procedure of Folch et al. (1957) [36] was followed in order to determine the lipid from algal biomass. Briefly, the biomass was dried at $90^{\circ} \mathrm{C}$, and a measured quantity of dry homogenized biomass was extracted three times with a mixture of chloroform/methanol $(2: 1)$. The biomass was removed by filtration through a filter paper, and the extracted lipids were transferred quantitatively to a tared Erlenmeyer flask. The procedure was repeated three times in order to extract all the lipids. The flask was fitted to a rotary evaporator (IKA RV 10, IKA, Staufen, Germany) until the FOLCH reagent was removed. The flask was allowed to cool to ambient temperature in a desiccator and then was weighed. The weight difference corresponded to intracellular lipids. At the end of cultivation, on the 16th day, 
the total biomass recovered from all the 10 flasks was $11.24 \mathrm{~g}$, while the lipid conversion was $1.69 \mathrm{~g}$.

\subsection{Transesterification of Algal Lipid}

Before biodiesel was analyzed in a gas chromatograph, lipid had to be converted to fatty acid methyl esters (FAMEs) via transesterification. The catalysts used in this study were biochar produced from MSR, CSG, and OK, pyrolyzed at 400 and $850^{\circ} \mathrm{C}$. For comparative purposes, sulfuric acid and sodium hydroxide were also used as catalysts. The experiments were carried out with a methanol to oil molar ratio of 600:1 and the catalyst to lipid molar ration of $0.35: 1$. The molecular weight of microalgae was considered to be $845 \mathrm{~g} / \mathrm{mol}$. Reactions were carried out at $60^{\circ} \mathrm{C}$, and the samples were centrifuged in a shaking agitator for $20 \mathrm{~h}$ at a stirring speed of $200 \mathrm{rpm}$ (Inova 43, New Brunswick Scientific, Enfield, CT, USA). The algal residue was then separated from the solution by centrifugation at $5000 \mathrm{U} / \mathrm{min}$ for $5 \mathrm{~min}$ in a centrifuge (mlw T52.1, GDR). Finally, qualitative and quantitative analysis of FAMEs was performed using a gas chromatograph (Agilent 7890A) equipped with a column Zebron ZB-FAME Phenomenex (LxIDxdf: $30 \mathrm{~m} \times 0.25 \mathrm{~mm} \times 0.20 \mu \mathrm{m}$ ) and a flame ionization detector. The assay conditions were as follows: oven temperature $240{ }^{\circ} \mathrm{C}$, inlet temperature $250{ }^{\circ} \mathrm{C}$, detector temperature $285^{\circ} \mathrm{C}$. Helion gas was used as a carrier gas at a flow rate of $1 \mathrm{~mL} / \mathrm{min}$. FAMEs-37 (Supelco 37 Component FAME Mix) standard samples were determined and quantified, while the analysis of the samples was performed by means of a standard solution of margaric acid (C17:0).

\section{Conclusions}

Biochars are environmentally friendly, low-cost, and reusable catalysts. The transesterification process is influenced mainly by the type of selected catalyst. Two significant parameters affect the effectiveness of biochar: the starting biomass and the pyrolysis temperature. At low pyrolysis temperature, the carbon phase was similar, irrespective of the raw biomass, while at high temperatures, the amount of minerals changed. Homogeneous catalysts $\left(\mathrm{H}_{2} \mathrm{SO}_{4}\right.$ and $\left.\mathrm{NaOH}\right)$ had similar results to the biochar CSG at $400{ }^{\circ} \mathrm{C}$ (the most productive tested biochar). MSR and CSG biochar, as catalysts, showed that pyrolysis temperatures affected the FAMEs recovery, while with the OK, no significant differences were observed.

Author Contributions: V.D.T.: investigation, formal analysis, and writing; A.F.A.: investigation, writing-reviewing; J.V.: investigation, reviewing, and editing; I.D.M.: conceptualization, funding acquisition, and editing. All authors have read and agreed to the published version of the manuscript.

Funding: V.D.T., A.F.A., and I.D.M. acknowledge support of this work by the project "Development of a novel attached algal photobioreactor for wastewater treatment and biomass production" (MIS 5047157) under the call for proposals "Human Resources Development, Education and Lifelong Learning 2014-2020" (EDULLL 103). The project is co-financed by Greece and the European Union (European Social Fund-ESF) by the Operational Programme Human Resources Development, Education and Lifelong Learning 2014-2020.

Acknowledgments: The authors would like to thank Katerina Govatsi from the Laboratory of Electron Microscopy and Microanalysis of the University of Patras for recording the SEM images.

Conflicts of Interest: The authors declare no conflict of interest.

\section{References}

1. European Commission. 2050 Long-Term Strategy. Available online: https://ec.europa.eu/clima/policies/strategies/2050_en (accessed on 5 July 2021).

2. Zhang, M.; Xu, Y.; Williams, B.L.; Xiao, M.; Wang, S.; Han, D.; Sun, L.; Meng, Y. Catalytic materials for direct synthesis of dimethyl carbonate (DMC) from $\mathrm{CO}_{2}$. J. Clean. Prod. 2021, 279, 123344. [CrossRef]

3. Zhang, M.; Alferov, K.A.; Xiao, M.; Han, D.; Wang, S.; Meng, Y. Continuous Dimethyl Carbonate Synthesis from $\mathrm{CO}_{2}$ and Methanol Using Cu-Ni@VSiO as Catalyst Synthesized by a Novel Sulfuration Method. Catalysts 2018, 8, 142. [CrossRef] 
4. Yang, Q.; Mašek, O.; Zhao, L.; Nan, H.; Yu, S.; Yin, J.; Li, Z.; Cao, X. Country-level potential of carbon sequestration and environmental benefits by utilizing crop residues for biochar implementation. Appl. Energy 2021, 282, 116275. [CrossRef]

5. Aravantinou, A.F.; Manariotis, I.D. Effect of operating conditions on Chlorococcum sp. growth and lipid production. J. Environ. Chem. Eng. 2016, 4, 1217-1223. [CrossRef]

6. Doussineau, M.; Gomez, J.; Holstein, F. Smart Specialisation and Blue Biotechnology in Europe; EU Publications: Luxembourg, 2020; ISBN 9789276277538.

7. Tsavatopoulou, V.D.; Vakros, J.; Manariotis, I.D. Lipid conversion of Scenedesmus rubescens biomass into biodiesel using biochar catalysts from malt spent rootlets. J. Chem. Technol. Biotechnol. 2020, 95, 2421-2429. [CrossRef]

8. Jo, S.W.; Do, J.M.; Na, H.; Hong, J.W.; Kim, I.S.; Yoon, H.S. Assessment of biomass potentials of microalgal communities in open pond raceways using mass cultivation. PeerJ 2020, 8, e9418. [CrossRef]

9. Aravantinou, A.F.; Theodorakopoulos, M.A.; Manariotis, I.D. Selection of microalgae for wastewater treatment and potential lipids production. Bioresour. Technol. 2013, 147, 130-134. [CrossRef]

10. Chamola, R.; Khan, M.F.; Raj, A.; Verma, M.; Jain, S. Response surface methodology based optimization of in situ transesterification of dry algae with methanol, $\mathrm{H}_{2} \mathrm{SO}_{4}$ and $\mathrm{NaOH}$. Fuel 2019, 239, 511-520. [CrossRef]

11. Tsavatopoulou, V.D.; Aravantinou, A.F.; Manariotis, I.D. Biofuel conversion of Chlorococcum sp. and Scenedesmus sp. biomass by one- and two-step transesterification. Biomass Convers. Biorefinery 2019, 11, 1301-1309. [CrossRef]

12. Vakros, J. Biochars and Their Use as Transesterification Catalysts for Biodiesel Production: A Short Review. Catalysts 2018, 8, 562. [CrossRef]

13. Zhang, M.M.; Fu, Z.; Xiao, M.; Yu, Y.; Wang, S.; Choi, M.J.; Meng, Y. Synthesis of $\mathrm{Co}_{1.5} \mathrm{PW}_{12} \mathrm{O}_{40}$ and its catalytic performance of completely converting methanol to ethylene. Chem. Commun. 2016, 52, 1151-1153. [CrossRef]

14. Chi, N.T.L.; Anto, S.; Ahamed, T.S.; Kumar, S.S.; Shanmugam, S.; Samuel, M.S.; Mathimani, T.; Brindhadevi, K.; Pugazhendhi, A. A review on biochar production techniques and biochar based catalyst for biofuel production from algae. Fuel 2021, $287,119411$. [CrossRef]

15. Manariotis, I.D.; Fotopoulou, K.N.; Karapanagioti, H.K. Preparation and Characterization of Biochar Sorbents Produced from Malt Spent Rootlets. Ind. Eng. Chem. Res. 2015, 54, 9577-9584. [CrossRef]

16. Avramiotis, E.; Frontistis, Z.; Manariotis, I.D.; Vakros, J.; Mantzavinos, D. Oxidation of sulfamethoxazole by rice husk biocharactivated persulfate. Catalysts 2021, 11, 850. [CrossRef]

17. Ntaflou, M.; Vakros, J. Transesterification activity of modified biochars from spent malt rootlets using triacetin. J. Clean. Prod. 2020, 259, 120931. [CrossRef]

18. Vakros, J.; Manariotis, I.D.; Dracopoulos, V.; Mantzavinos, D.; Lianos, P. Biochar from spent malt rootlets and its application to an energy conversion and storage device. Chemosensors 2021, 9, 57. [CrossRef]

19. Orfanos, A.G.; Manariotis, I.D.; Karapanagioti, H.K. Removal of methylene blue from water by food industry by-products and biochars. Desalin. Water Treat. 2018, 103, 113-121. [CrossRef]

20. Ntzoufra, P.; Vakros, J.; Frontistis, Z.; Tsatsos, S.; Kyriakou, G.; Kennou, S.; Manariotis, I.D.; Mantzavinos, D. Effect of sodium persulfate treatment on the physicochemical properties and catalytic activity of biochar prepared from spent malt rootlets. J. Environ. Chem. Eng. 2021, 9, 105071. [CrossRef]

21. Brindhadevi, K.; Anto, S.; Rene, E.R.; Sekar, M.; Mathimani, T.; Chi, N.T.L.; Pugazhendhi, A. Effect of reaction temperature on the conversion of algal biomass to bio-oil and biochar through pyrolysis and hydrothermal liquefaction. Fuel 2021, 285, 119106. [CrossRef]

22. Sotoudehniakarani, F.; Alayat, A.; McDonald, A.G. Characterization and comparison of pyrolysis products from fast pyrolysis of commercial Chlorella vulgaris and cultivated microalgae. J. Anal. Appl. Pyrolysis 2019, 139, 258-273. [CrossRef]

23. Magioglou, E.; Frontistis, Z.; Vakros, J.; Manariotis, I.D.; Mantzavinos, D. Activation of persulfate by biochars from valorized olive stones for the degradation of sulfamethoxazole. Catalysts 2019, 9, 419. [CrossRef]

24. Bekatorou, A.; Kopsahelis, N.; Mallouchos, A.; Plessas, S.; Droushiotis, N.; Kanellaki, M.; Komaitis, M.; Koutinas, A.A.; Nigam, P. Biotechnological exploitation of brewery solid wastes. In Current Topics on Bioprocesses in Food Industry; Rao, L.V., Pandey, A., Larroche, C., Soccol, C.R., Dussap, C.G., Eds.; Asiatech Publishers Inc.: New Delhi, India, 2010; pp. 193-209.

25. Kemmou, L.; Frontistis, Z.; Vakros, J.; Manariotis, I.D.; Mantzavinos, D. Degradation of antibiotic sulfamethoxazole by biocharactivated persulfate: Factors affecting the activation and degradation processes. Catal. Today 2018, 313, 128-133. [CrossRef]

26. Gao, G.; Cheong, L.Z.; Wang, D.; Shen, C. Pyrolytic carbon derived from spent coffee grounds as anode for sodium-ion batteries. Carbon Resour. Convers. 2018, 1, 104-108. [CrossRef]

27. Andrade, T.S.; Vakros, J.; Mantzavinos, D.; Lianos, P. Biochar obtained by carbonization of spent coffee grounds and its application in the construction of an energy storage device. Chem. Eng. J. Adv. 2020, 4, 100061. [CrossRef]

28. Thoai, D.N.; Tongurai, C.; Prasertsit, K.; Kumar, A. Review on biodiesel production by two-step catalytic conversion. Biocatal. Agric. Biotechnol. 2019, 18, 101023. [CrossRef]

29. Piloto-Rodríguez, R.; Sánchez-Borroto, Y.; Melo-Espinosa, E.A.; Verhelst, S. Assessment of diesel engine performance when fueled with biodiesel from algae and microalgae: An overview. Renew. Sustain. Energy Rev. 2017, 69, 833-842. [CrossRef]

30. Knothe, G. “Designer” biodiesel: Optimizing fatty ester composition to improve fuel properties. Energy Fuels 2008, 22, 1358-1364. [CrossRef] 
31. Prommuak, C.; Pavasant, P.; Quitain, A.T.; Goto, M.; Shotipruk, A. Microalgal lipid extraction and evaluation of single-step biodiesel production. Eng. J. 2012, 16, 157-166. [CrossRef]

32. Shalaby, E.A. Algae as promising organisms for environment and health. Plant. Signal. Behav. 2011, 6, 1338-1350. [CrossRef]

33. Fang, Y.R.; Yeh, Y.; Liu, H.S. A novel strategy of biodiesel production from wet microalgae by direct saponification-esterification conversion (DSEC). J. Taiwan Inst. Chem. Eng. 2018, 83, 23-31. [CrossRef]

34. APHA/WEF/AWWA. Standard Methods for the Examination of Water and Wastewater, 25th ed.; American Public Health Association: Washington, DC, USA, 1989; pp. 1-101. ISBN 9780875532356.

35. Salama, A.R.A.; El-Sahn, M.A.; Mesallam, A.S.; Shehata, A.M.E.T. The chemical composition, the nutritive value and the functional properties of malt sprout and its components (acrespires, rootlets and husks). J. Sci. Food Agric. 1997, 75, 50-56. [CrossRef]

36. Folch, J.; Lees, M.; Sloane Stanley, G.H. A simple Method for the Isolation and purification of total lipides from animal tissues. J. Biol. Chem. 1957, 226, 497-509. [CrossRef] 